INVESTIGATIONES LINGUISTICAE VOL. XL, 2018

(C) INSTITUTE OF LINGUISTICS - ADAM MICKIEWICZ UNIVERSITY

AL. NIEPODLEGŁOŚCI 4, 60-874, POZNAŃ - POLAND

\title{
Incipient Musings on Theory and Formation of Modern Korean Digraphia
}

\author{
William Strnad \\ Faculty of Modern Languages and Literatures, Adam Mickiewicz University \\ al. Niepodległości 4, 61-874 Poznań \\ wjstrnadiii@yahoo.com
}

\begin{abstract}
This article explores modern Korean digraphia, its chracteristics, duality and formation. The author posits that the essential axis of argumentation of the Korean digraphic debate related to the applications of Chinese characters and Korean phonetic script was formed by the early part of the twentieth century, and would be recapitulated in the two Koreas against the backdrop of postcolonial metanarration and Cold War politics. The author asserts that the functional and synchronic nature of modern Korean digraphia was formed under the influence of the Lyotardian modernity emancipation and speculative (science) metanarratives, as well as the discourse of modern Korean nationalism, which synchronically formed in the Korean assertion of national identity and idependence, during Korea's struggle against imperialism.
\end{abstract}

\section{Introduction}

It can be asserted that digraphia in some form existed prior to the invention of the Korean phonetic script in the fifteenth century, given the existence of such script forms as idu, hyangch'al, and kugyŏl, all of which used Chinese characters to replicate spoken Korean (J. W. Kim, 2007). However, specific to the focus of this work and based on scholarship on the parameters of digraphia, with the 1443 invention of hunmin chŏng ŭm, later to be termed "vulgar script” (ŏnmun), "national script" (kungmun), and finally, han'gŭl or chosŏn'gŭl, there existed a synchronic form of digraphia, or the simultaneous existence of two writing 
systems within one language community, which is the most essentialist definition of digraphia (Zíma, 1974; Ferguson, 1959; Dale, 1980; DeFrancis, 1984).

Hannas writes that hunmin chŏng'ŭm, "for most of its history was regarded as a poor person's substitute for real writing”, which was either classical Chinese (hanmun) or Korean using Chinese characters to approximate the phonetics of spoken Korean (Hannas, 1997: 51; also in M. S. Kim, 1973). Wang Sinxiang's study of Korean court interpreters of the Chinese language seemed to indicate a tendency of Koreans of early and middle Chosŏn toward graphocentrism, who demeaned spoken communication, and elevated the value of the written word (Wang, 2014: 2014: 41-42); hunmin chŏng’ŭm, or ŏnmun was associated with spoken communication because of its phonetic rendering of spoken Korean. Generations of Confucian scholars in Korea following the fifteenth century promulgation of Korea's phonetic script, continued to refer to hanja as "real script" (chinmun,) or "real writing" (chinsŏ), denoting the script leading to true or real enlightenment and knowledge (Schmid, 2002: 66). The author distinguishes previous historical digraphias related to the Korean language from the formation and practice of "modern Korean digraphia", which can be defined as the relationship between popularized Korean script and "mixed script" (honyongkukhanmun or kukhanmun), from the late nineteenth century through the present when Korean ŏnmun began to challenge the previously held dominant position of "classical Chinese" (hanmun), and in the two postliberation Koreas when hanja was used with han'gŭl (chosŏn'gŭl), was used in some print media in the South, and as part of national education curriculum in both the North and South, which remains true to the present.

\section{Digraphia and Modern Korean Digraphia \\ 2.1 Definitions and Characteristics}

Stéphane Grivelet (2001) writes that Petr Zíma (1974) was one of the first scholars to propose the concept of digraphia (Berlanda, 2006: 10). The term digraphia, the use of two (or more) writing systems for representing a language, was originally coined by Zíma as a parallel to Charles A. Ferguson's concept of diglossia (1959), according to Peter Unseth (2005: 36). Diglossia refers to the use of two varieties of a language which coexist in a speech community at the same 
time and of which one is used as a high status (H) and one as a low status (L) variety (Ferguson, 1959; Dale, 1980: 5). Zíma distinguishes between diorthographia and digraphia, defining diorthographia as a situation in which "two types of written form of a particular language co-exist, using the same script, but they are based upon the usage of two distinct orthographies by the same language community" (Zíma, 1974: 58) Zíma then defines digraphia as an instance when "two types of written form of one language co-exist, based upon the usage of two distinct graphical systems (scripts) by the respective language community" (Ibid.: 60).

Building on Zíma's original concept, that digraphia was exclusively a synchronic phenomenon, Ian R. H. Dale defines digraphia as "the use of two (or more) writing systems for representing a single language (or varieties thereof)", (Dale, 1980: 5), and distinguishes between synchronic and diachronic (historical) digraphia, which is an extension of Ferdinand de Saussure's division between synchronic linguistics and diachronic linguistics (de Saussure, 1916, 2011). Dale writes that synchronic digraphia is "more than one writing system used contemporaneously for the same language", while diachronic digraphia is "more than one writing system for a given language in successive periods of time". Dale emphasizes that whenever digraphic examples are analyzed, their social, cultural and political backgrounds, which give rise to their existence, have to be closely examined (Dale, 1980: 5-6).

Dale's 1980 article was a focal point for the development of contrasting definitions of digraphia. John DeFrancis, referring to Zíma's and Dale's definitions, defines digraphia as "the use of two or more different systems of writing the same language" (DeFrancis, 1984: 59), but uses Ferguson's notion of high and low status scripts to describe pinyin as representing (L) and Chinese characters representing $(\mathrm{H})$. DeFrancis (Ibid.: 60) uses the terms "concurrent" and "sequential" instead of Dale's "synchronic" and "diachronic". Grivelet (2001) explains digraphia as "a single sociolinguistic process with two types of outcomes (concurrent or sequential digraphia) and with specific features related to the causes and types of development of the various cases" (Grivelet, 2001: 6). Peter Unseth (2005) mentions three different ways that the term digraphia can be understood: as two scripts being used for one language; as script changes for one 
language over a certain period of time; and as the multiplicity of scripts being used for different languages which are all present in one speech community. Unseth's important contribution to the scholarly literature on digraphia concerns similarities between choosing scripts and choosing languages, that the sociocultural significance of scripts is that they are like symbolic "flags" for entire language communities (Unseth, 2005: 19-20, 36). Lastly, following Grivelet's characterization of digraphia as a process rather than a static condition, Elena Berlanda (2006) writes the following:

The definition of digraphia ... less as a set of specific categories which can be opted for by a community but rather as a force which is always at work. This means that languages, being written or not, always have a certain relation to literacy. While languages are generally in a state where they are in a relationship with literacy the form of this relationship takes (i.e. the type of literacy option that is chosen) is influenced by motivations and goals of a speech community (Berlanda, 2006: 110).

The typologies of digraphia remains an issue of debate, and has been meticulously addressed in Berlanda (2004), who suggests three categories, additive, subtractive and diachronic, instead of two categories of digraphia as proposed by Dale, namely diachronic and synchronic (Dale, 1980: 6). In her 2004 examination of digraphia, Berlanda observes that though additive digraphia leads to a period of coexistence of two or more scripts, elimination can occur; this can also be a case of a quasi "drawn out script change" (Berlanda, 2004: 82) where reform does not occur swiftly enough. Berlanda finds that for a theoretical discussion on the subject, it is useful to keep the three possibilities, adding, eliminating and changing (switching), separate. In addition to recognition of Dale's concept to diachronic, Berlanda summarizes the types of additive digraphia as follows: synchronic (different scripts employed in one language according to a social factor like, for example, religion); structural (different scripts employed in one language according to different grammatical structures, such as Hindi/Urdu or Serbian/Croatian) (Rivlina, 2015); and functional (different scripts used according to certain domain or register differences, resulting in mixed script, such as Japanese, and to a lesser degree, Korean), or what J. Marshall Unger describes as "partial digraphia" (Unger, 2001: 151). 
Furthermore, Berlanda suggests that subtractive digraphia, that is the elimination of a script, are due to one of the three reasons: (1) social factors; (2) grammatical factors; and (3) domain or register (Berlanda, 2004: 82-83).

Unseth (2005: 35) observes that historically Korean exhibited diachronic or sequential digraphia in that "a gradual change of script can be seen in the change from writing Korean in hanja to han'gŭl (a process that arguably nearly spanned five centuries)". Berlanda (2004) assesses that contemporary Korean digraphia exhibits features of both structural digraphia, and subtractive digraphia of the second kind (elimination of a script due to grammatical factors), though this is not completely the case, as in both North and South Korea, elimination of hanja, was reversed as attempts at establishing han'gŭl (chosŏn'gŭl) exclusivity. Despite the structural distinctions, according to which the different scripts are used, certain domain differences can also be observed in South Korean use, where hanja often appears, particularly in official and public documents, as well as in some scholarly texts (Hannas, 1997: 54), suggesting elements of functional digraphia.

\subsection{Considering Duality}

The definitions of digraphia rendered by both Grivelet (2001) and Berlanda (2004) have a particular resonance, as it relates the theme of this article: that modern Korean digraphia has been a dynamic process. In conceptualizing modern Korea's digraphic conflict the author of this article originally conceived of the term "Korean script binary" (Strnad, 2016: 93, 112-113). A denotative definition of a binary, used as a noun, is a thing that consists of two components, elements, or parts. The term binary is used in conjunction with such terms as binary star system, suggesting that two parts comprise a single entity. Other definitions are of two stable oppositional elements that can be used to create an analytical or structural model, as in "the binary opposition of male and female" (Miriam-Webster Dictionary, 2017). The dialectic or duality of the choice of the word "binary" correlates with descriptions throughout the literature of sociolinguistics. Dale observes that the two primary factors operating in a language community related to script choice are the prevailing cultural influence and the prevailing political influence. Dale explains that digraphia occurs "when 
more than one such influence is in operation and none can dominate all groups of speakers of the language in question" (Dale, 1980: 12). The Korean example is a variation of Dale's premise: in Korea, from the late nineteenth century into the contemporary period, the source of digraphia, that is, the motivations and lines of argument regarding script, consisted of both cultural and political reasoning.

The term binary raises questions as to the nature of the self-contained duality Korean digraphia; specifically, whether Korean digraphia and Korean digraphic conflict should be interpreted as dialectic, as opposed to dialogic. The contrasting axis of dialogic versus dialectic is found in the field of sociolinguistics; these concepts are used in scholarly literature pertaining to issues of group identity and national identity. The term binary, however, proved to be problematic in terms of denotative and connotative interpretations that could be too broad, and consequently the author re-examined the phenomenon of digraphic conflict elsewhere and derived the phrase "digraphic identity dissonance" (author's quotation marks) to address the source of conflict, being identity in relationship to script. The term "identity dissonance" is utilized in scholarly literature ranging in fields such as professional identity and religious experience. The term digraphic identity dissonance, defined as synchronic discord between script and identity within a single speech community is currently clearly exhibited in Serbia (Latin and Cyrillic) as a form of genre digraphia, suggestive of national identity among some Serbian speakers (Canakis, 2018: 235-245), and Kashmir (Arabic and Devanagari) reflecting a division of Kashmiris along religious lines between adherents of Islam and Hinduism (Bhat, 2017: 81-82). This can be contrasted with an absence of digraphic (at least trigraphic) identity dissonance among speakers of Japanese, who can utilize a mixed script with kanji, hirakana, katakana, and romanji, without any dissonance (Hannas, 1997: 299-300).

The phrase "digraphic identity dissonance" coined by the author of this article is more to the point, and permits a comparative examination of modern Korean digraphia to be compared with other contemporary forms of synchronic digraphia, and through a cursory examination of the two processes, dialogic and dialectic, the author will articulate a characterization of the Korean script binary as dialectic rather than dialogic. Dialogic processes imply the coexistence of oppositional forms, as exemplified by Mikhail M. Bakhtin's dialogism (1981), which suggest intersubjectivity and constitutes a rejection of essentialist views of 
essence and that culture is emergent and dynamic, and that there is no last word in dialogue (Thompson, 2012: 92). In dialogic phenomena ideologies remain existentially separate, though both can be open on-going accommodation. Dialectic processes on the other hand, as described by Lev S. Vytgotsky (1934, 1986: 255; also cited in Thompson, 2012: 91-92), are Hegellian in nature, in that there is an interaction and resolution between multiple paradigms or ideologies, with oppositional elements. The point and counterpoint, or the thesis and antithesis, can either struggle for hegemony of one form over others, or merge into a compromise by means of conflict and tension, or a synthesis, sometimes creating a new conflict or tension (Eisenstein, 1949, 1977: 45-47, 111).

Paul Thompson (2012) and Stuart Hall (1996) both observe that dialogics and dialectics are not mutually exclusive. Hall suggests that much of Valentin N. Volosinov's (1929, 1973) dialectics resembles Bakhtin's (1984) dialogic arguments, and references Volosinov's concept of "multi-accentuality” of the sign (Hall, 1996: 295). For Volosinov, signs do not have one meaning but possess an "inner dialectical quality" and an "evaluative accent" which makes them capable of signifying a range of meanings. Bakhtin observes that signs do not have fixed meanings, but instead, a sense of meaning is generated within a two-sided relationship. In any case, "both" suggest that meaning cannot be guaranteed, it is not pure but always ambivalent and ambiguous. Meaning is the inherently unstable domain of contestation. Discourse, identities and social practice in time and space form a mutually constituting set implicated in the cultural politics of identity (Hall,1996: 295-297; Barker and Galasiński, 2002: 44).

The question of duality, meaning the historical values assigned to han'gŭl and hanja, is relevant to the intersection of LPP and nationalism in the two Koreas addressed in this work. Dualism is part of the framework of both dialogic and dialectic approaches in the theoretical literature of sociolinguistics. Volosinov $(1929,1973)$ says that the inner dialectic quality of linguistic signs emerges into the open during periods of social crises or revolutionary changes. Volosinov argues that a stable system of linguistic signs is merely a scientific abstraction; the generative process of language is implemented in the social-verbal interaction of speakers; the laws of language generation are sociological laws. Both proponents of dialectical and dialogic processes agree that language inevitably 
has an internal conflictual struggle. Volosinov suggests that language can be conceptualized as both "reflecting" and "refracting" ideology (Volosinov 1929, 1973: 9, cited in Gurden, 1994: 64). Bakhtin writes that there are "centripetal" and "centrifugal" forces of language. Centripetal forces, such as state-sponsored language planning and policy initiatives, seeking to impose a unified frame for linguistic, ideological, and political interpretation and expression, are in opposition to centrifugal forces, the spatial-temporal grounding of language in social context that prevents unitary frames of usage from taking hold (Bakhtin, 1981: 270; Bostad et al., 2004: 1-19).

The author of this article recognizes that there is substantial overlap between the two concepts of dialogics and dialectics in addressing the nature of Korean digraphia, or in Harald Haarman's words, the Korean "digraphic conflict" (Haarman, 1993: 144), and therefore, the Korean script binary. The period of script policies in North and South Korea during the years 1945-1972, arguably having manifesting characteristics of both dialogism and dialecticism. Nonetheless, considering the denotative parameters of the two terms, the author concludes that "dialectic" is more suitable: both nations by the early 1970 arrived at a "compromise" or "synthesis": the language policies of North and South Korea by 1972, had arrived at a rejection of absolute han'gŭl (chosŏn'gŭl) exclusivity is rejected, and hanja was included in the educational programs of both nations, and continued to be used in South Korea in selected print media, such as official government documents, selected academic works and family genealogies, as examples (Ibid.).

"Dialectics" figure prominently in critical discourse analysis (CDA) literature, which can be applied to the problem of Korean digraphia. Norman A. Fairclough insists that "dialectical relations are relations between objects which are different from one another, but not what I shall call 'discrete', not fully separate in the sense that one excludes the other" (Fairclough, 2010: 3-4). The dialectic within texts, including extant narratives of any given historical period are, according to Ruth Wodak (2007), often the sites of struggle between differing discourses and ideologies contending and struggling for dominance. This dialectic does not deal with mere enactment and inculcation. Fairclough writes that social life is reflexive, meaning that human beings, and indeed groups of human beings, "not only act and interact within networks of social practices", but "interpret and represent to 
William Strnad: Incipient Musings on Theory and Formation

of Modern Korean Digraphia

themselves and each other what they do, and these interpretations and representations shape and reshape what they do" (Fairclough, 2010: 4). Korean digraphia is, in the assessment of the author, is an exemplification of an ideological struggle over the signification of signs (Volosinov, 1929, 1973: 23), coming to a contentious synthesis the late nineteenth century, through to the time of the emergence of the two Koreas.

\section{More Notes on Modern Korean Digraphia 3.1 Formation and Essential Structure}

The first Korean government action on behalf of language reform, and specifically, the launch of modern Korean digraphia, came in the form of a royal edict in the wake of the 1894 Kab'o Reforms. The 21 November 1894, Edict on Public Writing (Kongmunsik), written in hanmun and "national scripr"

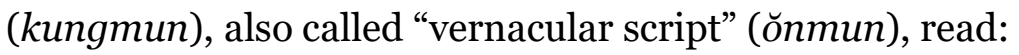

All laws and decrees shall have kungmun as a base; mixed-script versions (honyongkukhanmun) may be attached (Kab’ogyŏngjang, 1894, author's translation).

Pieper observes that this was the first instance that ŏmmun was officially designated as national script (kungmun), demonstrating a nation-language association and suggesting an Japanese ideological influence (Pieper, 2011: 4445; C. G. Pak 2012: 162, 281). However, neither the government nor any private individuals took any concrete steps to promote the use of kungmun following this edict, and "mixed script" (honyongkukhanmun or kukhanmun) continued its ascendance (King, 1998: 37). Yi Ki-mun (1987) posits that hanmun could not have been dislodged from its privileged status, and be replaced by ŏnmun, without the dynamics of a revolution; Yi concludes that the "revolution" was the royal edict (K. M. Yi, 1987, cited in H. H. Em, 1999: 352). According to Henry H. Em, at least in terms of the historic trajectory of Korean script, and therefore, the character of modern Korean digraphia, the revolution of the 1894 Edict on Public Writing as part of the Kab'o Reforms, derived it energy from various centrifugal movements in Korea that had been undermining the authority of the Chosŏn dynasty $(H$. H. 
Em, 1999a: 352; anslo in H. H. Em, 1999b). North Korean historian Kim Yŏnghwal (1978: 475) on the other hand, stresses that the inclusion of mixed-script was symbolic of the limitations of the reform, or "bourgeois nationalism" (also in C. H. Ri, 1991). Yi Hye-ryŏng (2005) emphasizes the importance of "hanja perception" in late Chosŏn and how this shifting perception both reflected the changing relationship between Korea and China and in turn influenced further discussion on the topic in the popular press. More importantly, Yi states that the transformation in the popular perception of hanja/hanmun represented a fundamental turn in the entire East Asian episteme, and broadly, the collapse of the Sino-centric world. Christoph Jan Janasiak assigns importance to the edict of the reforms, but asserts that the power of the press during the years 1896-1910, with its use of ŏmmun, constituted a gradual and final "degradation of the hanmun system” in Korea (Janasiak, 2012: 164-167).

Scholarly discourse among Koreans during the first decade of the twentieth century would foreshadow gradations of limited hanja use proponents in both post-1945 North and South Korea. The debates in the years 1905-1910 relevant to Korean digraphia, were primarily along a discourse axis, or an "axis of argumentation" (author's term) between kungmun exclusivity and kukhanmun, though both camps agreed on some basic objectives for the Korean language reform movement: kungmun promotion and standardization, the elimination of hanmun as a standard style of communication, or a limitation on hanmun, or hanja use. Pieper (2011) comments that the public response from hanmun supporters during the first decade of the twentieth century was conspicuously muted. Based on textual examination of argumentation points in both North and South Korean digraphia and script policy, the author of this article opines that many of the same essential axes of argumentation regarding choice of script among Koreans formed in the first decade of the twentieth century, particularly in the period 1905-1910, formed the structure of modern Korean digraphic debate that would be recapitulated in language policy discourse related to script in the two post-liberation Koreas. Ross King (1998), in his study of the Korean language question in precolonial Korea, articulates the axis of argumentation concerning Korean digraphia during the five years prior to the Japanese annexation of Korea, as matters related to script increasingly became associated with with the development of modern Korean nationalism during the first decade of the 
William Strnad: Incipient Musings on Theory and Formation

of Modern Korean Digraphia

twentieth century (G. W. Shin, 2006).

Korea's independence from Chinese political hegemony at the turn of the century was a reality. The kungmun-only movement grew with the formation of modern Korean nationalism, constituting a linguistic nationalism (in the case of Korea, han'gŭl or chosŏn'gŭl nationalism) (J. J. Song, 1994: 206). By 1900, the use of classical Chinese (hanmun) as a written form of official communication was popularly seen as not being modern and a symptom of cultural dependence, reflected by the then growing use of the term "serving the great" (sadaejuŭi) (Robinson, 1988: 34), referring to what had been Korea's relationship with China. Kim Min-su (1973) observes that since the time of the Korean enlightenment ideology period there had been a proliferation of such ŏnmun (later kungmun) materials as the vernacular novels, referred to as "new novels" (sinsosŏl), and Christian bibles (sŏng'gyŏng); by the turn of the century ŏnmun materials had become ubiquitous. However, it was in the second half of the first decade of the twentieth century the "movement to eliminate hanja" (hanja-ŭi ch'ubang'undong) became ensconced in the public discourse of Koreans, as well as the axis of argumentation concerning script in Korea, which included "pure hanmun script" (sunhanmunch'e), "mixed script" (kukhanjach'e), and "pure national script" (sunkungmunch'e), meaning kungmun exclusivity (kungmunjong'yongnon) (M. S. Kim, 1973: 344; also in Pieper, 2011).

The Korean discourse concerning Korean digraphia during the decade preceding the Japanese annexation of Korea in 1910 focused on the macro-issue of script choice: namely, would the primary script for Korea be hanmun, kukhanmun, or pure kungmun be used. Articles supporting kukhanmun writing style were most prominent even up until the 1910 annexation, a trend reinforced by the majority of periodicals still being published in this style. The majority of editorials and articles championing kungmun were published in the kukhanmun style, owing to the lack of a clear, enforced standard for kungmun (Pieper, 2011: 57; E. H. Yi, 1974: 7-8).

A few of the major arguments used in support of both kungmun and kukhanmun, were fundamentally the same: easier to use, especially compared to hanmun, and part of Korean cultural heritage or legacy. Some advocates of kukhanmun, cited Japan as an example of a nation which had successfully 
blended Chinese characters with its own indigenous script (Yŏnseidae on'ŏjŏngboyŏn'guwŏn HKsaŏpdan, 2012; King, 1998: 62). Because the kukhanmun advocates supported the incorporation of some kungmun, they did not fundamentally oppose the idea of kungmun as the hanmun proponents did. According to Pieper (2011), the kungmun proponents repeated common themes: ease of learning, efficiency, the potential economic implications of an easy-tolearn script, loyalty and piety to King Sejong, independence, and national pride. The kukhanmun advocates cited reasons such as Japan's successful implementation of a mixed-script, East Asian identity, clarity and refinement of expression, and national pride, as well. However, where kukhanmun reformers perceived a gradual reduction in Chinese characters over time coupled with careful kungmun standardization, many kungmun supporters called for the immediate abolition of hanja from the Korean language (Pieper, 2011: 57-58).

According to Shim Jae Kee (1998: 9-10), this essential orientation or structure of the doctrine of han'gŭl exclusivity (han'gŭljŏn-yongnon), was formed by the end of the 1920s, and the beginning of the 1930s, a continued as an axis of debate among Korean scholars until the end of the second phase of Japanese occupation (1919-1937). The corollary of this is that the structure of modern Korean digraphia, that is, the characteristics of the narratives related to the two scripts, han'gŭl (or chosŏn'gŭl) and hanja (hanmun), had been formed and the discourse was fully integrated into debates on national identity, particularly on the part of ethnic nationalists, responding to communist internationalism and the policies of assimilation perpetuated by the Japanese colonial government (G. W. Shin, 2006: 68-73).

\subsection{Connecting Nationalism and Metanarration}

Shin Gi-Wook identifies the two primary currents in the formation of Korean nationalism as universalism (the logic of modernity in a Korea struggling to adapt and reform) and particularism (the logic of nation and nationalism to assert Korean identity) (also in Wallerstein, 1990). Shin elaborates on the distinction between the two:

By definition, universalism is the belief that ideas and practices can be applied everywhere without modification, while particularism is the belief 
that circumstances dictate how ideas and practices should be applied (G. W. Shin, 2006: fn. 1, 257).

These discourse elements contained in the process of Korean nationalism's genesis are explained by Shin Gi-Wook (2006) as consisting of two periods: the first period from the latter-half of the nineteenth century to the first decade of the twentieth century, dominated by references to national independence in the face of foreign encroachment, but also inequality, the plight of commoners, the social discord and class conflict of the late nineteenth century, and as a responsorial notion, the universalism of reform and modernity, to include the influence of Christianity; and in the second period, commencing in the first decade of the twentieth century through the end of the Japanese occupation, universalist elements were retained, however, discourse became increasingly characterized by the particularism of ethnic nationalism as a means of opposing the antiimperialism of Japanese aggression. During the Japanese occupation period, a defensive assertion of Korean identity countered the colonial repression and racist policies of the Japanese.

Shin argues that in the period of the 1890 s to the middle of the first decade of the twentieth century, Korean nationalism, as it was forming, was predicated upon the universalist values of modernization, in national response to the collapse of the Sino-centric world and the increasing influence of foreign powers; in the second period, from the middle of the first decade of the twentieth century, Korean nationalism's central narrative was a mixture of universalism and particularism, with a shift toward an ethnicization of Korean nationalism being conspicuous beginning during the years 1905-1907, and continued to grow in importance as Japan strengthened its domination of Korea. Shin has identified Korean ethnic nationalism as becoming the dominant discourse beginning in the mid-1930s. Many of the narratives and tropes of the modern Korean digraphic discourse, based on nationalism's development, were recapitulated in the postliberation period in both Koreas, as both the North and South negotiated national identity construction as post-colonial political entities (G. W. Shin, 2006: 39-40; Haarmann, 1993: 154-157).

The foundational components of modern Korean nationalism are relevant 
to the formation of narratives concerning the frequently oppositional relationship between hanja and han'gŭl (chosŏn'gŭl), with the Korean script being symbolic of both modernity and/or the essence of "true" Korean identity, whereas hanja being associated with the contradictions of pre-modern Korea: political incapacity and foreign domination by China, and later, conflated with Japanese colonialism and the Japanese use of kanji, while nonetheless, invoking a rich heritage of national scholarly brilliance. Michael E. Robinson (1986) observes that Korea's progression toward modern nationalism has a relevant parallel in the internal contradictions in China's interplay between tradition, reform thought, and a modern intellectual synthesis, including modern nationalism. Robinson notes Joseph R. Levenson's conclusion that modern Chinese nationalists in the nineteenth and twentieth centuries struggled with a rejection of the past as corrupt and decadent, while at the same time, given their "intellectual alienation from tradition" (Levenson, 1958, 1968: 98) in the cause of modernity and reform, attempted to enhance "national identity formation by selecting and emphasizing some aspects of tradition while rejecting others". (Robinson, 1986: 37). The fractured elements of Korean nationalism, that is, the inherently divided trajectory of modern nationalism, based on class conflicts and the process of both maintaining and rejecting traditional identity, was manifest in the modern Korean digraphia (hanja-han'gŭl), came to be defined along divides within Korean identity itself, and continued to recapitulate itself in the LLP of North and South Korea during the years 1945-1972. Andre Schmid's study of the Korean press during the years 1895-1919 (Schmid, 2002), reinforces Shin's model of of Korean nationalism's formation, which is echoed in Anthony D. Smith's valuation of the analysis of ethno-symbols, and the concept of a recapitulation of nationalism's symbols and narratives (Smith, 2009).

The elements of early modern Korean nationalism, the pulsing of discourse between universalism and particularism (ethnic nationalism) and the debates over script use as realted to national identity and nation in the early twentieth century, point to a quality of narrativity, suggesting narration and metanarration. A metanarrative is defined as a trans-historical narrative that is deeply embedded in a particular cultural context and can serve as a frame for other narratives or metanarratives (Stephens and McCallum, 1998: 214). A metanarrative is a narrative that is "transhistorical and deeply culturally embedded...coherent 
system of interrelated and sequentially organized stories that share a common rhetorical desire to resolve a conflict" (Halverson et al., 2011: 12, 14) discursive elements. Shin Gi-Wook (2006: 116-119, 129) has described the emergence of Korean nationalism as consisting of two periods with somewhat different narrative content, though the content of the narratives were never mutually exclusive. If indeed metanarratives are holistic, hierarchical frameworks, then the application of metanarrative to Korean nationalism, for example, is not problematic, as it is so termed by James F. Siekmeier (2017) referring to Latin American, and Yehudith Auerbach (2010) in discussing Israeli and Palestinian conflict. Lastly, Francisca Polletta (1998) and Margaret R. Somers (1992; 1994) both observing that narratives arising out of other narratives was of comfort to the author's conceptualizing metanarrative intersection related to modern Korean digraphia.

Presenjit Duara writes that the dominant narrative in both China and India during the late nineteenth and twentieth century related to nation and modernity were based on linear evolution, history unfolding based on a European Enlightenment model of history, stressing national progress toward modernity, regardless of cultural nexus or ideological inclination. Duara criticizes this metanarration of history of nation as having had a "contested and contingent false sense of unity", and as a result, placed the concept of nation between oppositional forces such as tradition and modernity, or hierarchy and equality (Duara, 1995: 3-4). Criticisms of the relevancy of Western models aside, Shin Gi-Wook observes that this was the dominant metanarrational structure applied to the development of Korean national identity; that is, the nation (minjok) was fixed on a trajectory toward modernity, from the time of the late nineteenth century into the twentieth century (G. W. Shin, 2006: 150). It is against this hegemonic backdrop that the axis of argumentation related to modern Korean digraphia was formed: through the awakening of modern Korean nationalism in the late nineteenth century, and the Korean struggle against anti-imperialism and Japanese colonial repression. This period is from the time of the Kabo Reforms (1894-1896), which was symbolic of the termination of the social status system of Chosŏn (Y. H. Shin, 1984; 1986), through the first decade of the twentieth century, the years 19041910, being termed as the period of the Patriotic Enlightenment Movement 
(Aegukgyemong'undong) during which Korean intellectuals debated change in response to imperialist incursions primarily by the Japanese (M. G. Kang, 1994, 2006: 297-301; also in Y. I. Lew, 1992; 2001 and Y. H. Shin, 1976; 2000).

The author of this article surmised that during the initial stages of reading and thought, the the discourse surrounding modern Korean digraphia communicated a kind of "sequentiality" (author's quotation marks for emphasis) or narrativity, and therefore, narrative and metanarrative scholarship became a primary focus. Fredric Jameson states that "the all-informing process of narrative" is "the central function or instance of the human mind" (Jameson, 1981: 16). Paul Ricoeur, amplifying the ideas of Martin Heidegger on time, situates narrative as vital to our essential cognitive activities. Ricoeur fuses narrativity and temporality in what he refers to as the "illusion of sequence" (Ricoeur, 1980: 169), which the author found compelling given the earlier coining of the term "sequentiality". Readings of Ricoeur led to increasingly in-depth readings of the works of Hayden White, which assert that history is narrative (White, 1973, 2014; 1980; 1984). Lastly, Jean-François Lyotard also asserts the essentiality of narrative, specifically within political critique and praxis, and that grand narratives explain modern history, albeit no longer necessary in the context of a post-modern condition (Lyotard, 1979, 1984: 48; summarized in Grinter, 2017). The author connected Lyotard's characterization of the two great modern metanarratives of humankind correlates with Shin Gi-Wook's observations and analysis of modern Korean nationalism, and therefore, the framework of the formation of modern Korean digraphia during the late nineteenth and early twentieth centuries.

Jean-François Lyotard $(1979,1984 ; 1988)$ posits that modernity is defined by its reliance upon the two "grand narratives" (metanarratives) (F. les grands récits) that depict human progress: the metanarrative of emancipation and the speculative metanarrative. Lyotard assessed that these two dominant metanarratives provided much of modern history with two comprehensive, explanatory, and thus legitimizing narrations about the world in terms of historical experience or knowledge, stating that "true knowledge is composed of a subject that guarantees legitimacy" (Lyotard, 1984: 35). According to William Schultz, Lyotard asserts that modernity itself, and therefore the two primary modernity metanarratives, begin as Christianity, develops and diversifies into various grand narratives up to the Enlightenment of the eighteenth century, 
through the nineteenth century, and are still being enacted in some form (Schultz, 1998), despite Lyotard's pronouncement of the death or irrelevance of these metanarrative traditions.

Lyotard describes the metanarrative of emancipation as giving hope to people that one day they will be free or that their situation will be better. It structures and justifies social institutions, political practices, laws, ethics, and ways of thinking in everyday life and dealings with other people, just as the myths of the classical period before them did. After Christianity, types of this social narrative are Enlightenment political rationalism, democracy, Romanticism, capitalism, and Marxism. Schultz observes that these types do not necessarily peacefully co-exist; for example, Romanticism as the interpretation of the will in terms of infinite enrichment is partially a reaction to capitalism as the interpretation of the will as infinite acquisition and domination (Schultz, 1998). This grand narrative presented knowledge as being valuable because and the emancipating first step toward human freedom. Here, "humanity is the hero of liberty. All people have a right to science" (Lyotard, 1979, 1984: 31). This grand narrative begins for Lyotard with the French Revolution in 1789, and the ideal that the masses will be liberated through mass-education (Ibid.: xxiii, cited in Knowles, 2011: 4). In this narrative knowledge is the basis of freedom from oppression, and human development in knowledge is valued because it sets humanity free from suffering. The aim of this grand narrative is the emancipation of an enlightened humanity from dogma, mysticism, exploitation, and suffering (summarized in Malpas, 2005: 26).

The speculative (scientific) metanarrative, or as Lyotard refers to as the "triumph of science", refers to the belief that knowledge forms an ideal unity, with the central notion being that human progress is achieved by increasing or perfecting knowledge; that "humanity makes progress through the increase of knowledge" (Knowles, 2011: 3). The speculative grand narrative originates in the German philosophy of the early nineteenth century, which found its most detailed form in the writings of Georg Wilhelm Friedrich Hegel (Lyotard, 1988: 35, 68, cited in Schultz, 1998, and in Malpas, 2005: 26). All the different language games are brought together by philosophy in order to present the Hegelian idea of a "universal history of spirit" (Lyotard, 1979, 1984: 34), that reality and history are 
understandable through a system of ideas (Malpas, 2005: 25-26). Steve Knowles explains that Lyotard understood Hegel as linking progress, and therefore modernity, to the sciences, resulting in a metanarration of a universal history of spirit, that "spirit is 'life', and 'life' is its own self-presentation and formulation in the ordered knowledge of all its forms contained in the empirical sciences" (Lyotard, 1979, 1984: xxiii, cited in Knowles, 2011: 3); that is, progress was increasing knowledge. Schultz writes that Lyotard advanced the notion that science itself, had somewhat replaced the speculative metanarrative, as the empirical sciences came into full expression in the nineteenth century (Schultz, 1998).

\section{Conclusions}

The marriage of intellecutal constructs relative to nationalism and metanarration form a redundancy of themes upon which modern Korean digraphia was formed and debated; the ideas survived Japanese occupation and colonial racism, and were ultimately subsumed in the politicized modernity metanarratives in South Korea and North Korea. Presenjit Duara (1995), in his exposition on Asia's embrace of the European Enlightenment model of history, is further amplified by the Lyotardian notion of the emancipation and speculative (scientific) metanarratives (Lyotard, 1979, 1984), reflected in the national metanarration of Korean nationalism with its often binary debate at the turn of the twentieth century characterized by universalism and the partcularism of ethnic nationalism (G. W. Shin, 2006). The author concludes that the undulating texture and terrain of modern Korean digraphia, that is, the voices that constitute its axis of argumentation are perhaps better understood as a variation of the phrase "to put in the abyss" (F. mise-en-abîme), meaning in art the postioning of a copy of an image within itself, or in film and literature, the telling of a story within a story, or as pertaining to the narrativity of modern Korean digraphic argumentation, metanarratives within metanarratives (Hayward, 2012: 239). 
William Strnad: Incipient Musings on Theory and Formation

of Modern Korean Digraphia

\section{References}

Auerbach, Yehudith 2010. National Narratives in a Conflict of Identity. In: Barriers to Peace in the Israeli-Palestinian Conflict. Ed. Yaacov Bar-Siman-Tov. 99-134. Jerusalem: The Jerusalem Institute for Israel Studies.

Bakhtin, Mikhail M. 1981. The Dialogic Imagination: Four Essays by M. M. Bakhtin. Ed. Michael Holquist. Trans. Caryl Emerson and Michael Holquist. Austin, TX: University of Texas Press.

Barker, Chris; Dariusz Galasiński. 2001. Cultural Studies and Discourse Analysis: A Dialogue on Language and Identity. London \& Thousand Oaks, CA: Sage Publications.

Berlanda, Elena 2006. New Perspectives on Digraphia: A Framework for the Sociolinguistics of Writing Systems. Major research paper. Toronto: York University.

Bhat, M. Ashraf 2017. The Changing Language Roles and Linguistic Identities of the Kashmiri Speech Community. Newcastle upon Tyne: Cambridge Scholars Publishing.

Bostad, Finn; Craig Brandist; Lars Siegfried Evensen; and Hege Charlotte Faber 2004. Introduction: Thinking Culture Dialogically. In: Bakhtian Perspectives on Language and Culture: Meaning in Language, Art and New Media. Eds. Finn Bostad; Craig Brandist; Lars Siegfried Evensen; and Hege Charlotte Faber. 1-19. Hampshire and New York: Palgrave MacMillan.

Canakis, Costas 2018. Contesting Identity in the Linguistic Landscape of Belgrade: An Ethnographic Approach. Belgrade English Language and Literature Studies (BELLS), Vol. 10, 229-258.

Dale, Ian R. H. 1980. Digraphia. International Journal of the Sociology of Language, Vol. $26,5-13$.

DeFrancis, John 1984. Digraphia. Word, Vol. 35, No. 1, 59-66.

de Saussure, Ferdinand 1916, 2011. Course in General Linguistics. Eds. Perry Meisel and Haun Saussy. Trans. Wade Baskin. New York: Columbia University Press.

Duara, Prasenjit 1995. Rescuing History from the Nation: Questioning Narratives of Modern China. Chicago, IL: University of Chicago Press.

Eisenstein, Sergei M. 1949, 1977. Film Form: Essays in Film Theory. Ed. and Trans., Jay Leyda. San Diego, CA, New York and London: Harcourt, Inc.

Em, Henry H. 1999a. Nationalism, Post-Nationalism, and Shin Ch'ae-ho. Korea Journal, Vol. 39, No. 2, Summer 1999, 283-317.

Em, Henry H. 1999b. Minjok as a Modern and Democratic Construct: Sin Ch'aeho's Historiography of Korea. In: Colonial Modernity in Korea. Eds. Gi-Wook Shin and Michael E. Robinson. 336-361. Cambridge, MA and London: Harvard University Press. 
Fairclough, Norman 1995, 2010. Critical Discourse Analysis: The Critical Study of Language. Second Edition. Abingdon, Oxon and New York: Routledge.

Ferguson, Charles A. 1959. Diglossia. Word, Vol. 15, No. 2, 325-340.

Grivelet, Stéphane 2001. Introduction. International Journal of the Sociology of Language, Vol. 150, 1-10.

Gurdin, Julie E. 1994. The Dialogic and the Semiotic: Bakhtin, Volosinov, Pierce, and Sociolinguistics. Arizona Anthropologist, Vol. 11, 57-69.

Haarmann, Harald 1993. The Emergence of Korean Script as a Symbol of Korean National Identity. In: The Earliest Stage of Language Planning: The "First Congress" Phenomenon. Ed. Joshua A. Fishman. 143-158. Berlin: Mouton de Gruyter.

Hall, Stuart (1996) For Allon White: Metaphors of Transformation. In: Stuart Hall: Critical Dialogues in Cultural Studies. Eds. David Morley and Kuan-Hsing Chen. 286-305. London: Routledge.

Halverson, Jeffrey R; H. Lloyd Goodall Jr.; Steven R. Corman 2011. Master Narratives of Islamist Extremism. New York: Palgrave MacMillan.

Hannas, William C. 1997. Asia’s Orthographic Dilemma. Honolulu: University of Hawai'i Press.

Hayward, Susan 2013. Cinema Studies: The Key Concepts. Fourth Edition. Abingdon, Oxon and New York: Routledge.

Janasiak, Christoph Jan. 2012. Wczesna prasa - modernizacja pisma i języka [The modern Korean press - modernization of writing and language]. Warsaw: Linguistica Asiatica Orientalia.

Kang, Man-gil 1994, 2006. Koch'y̆̌ ssŭn Han'guk kŭndaesa [A corrected writing of modern Korean history]. Seoul: Ch'angbi.

Kim, Min-su 1973. Kuk’ŏ chŏngch'aekron [Discussing national language policy]. Seoul: Koryŏdaehakkyo ch'ulp'anbu.

Kim, Yŏng-hwal 1978. Chosŏnminjokŏbaljŏnsayŏn'gu [A study on the developmental history of the Korean national language]. Ed. Ik-sŏ Ri. P’yŏngyang: Kwahak-baekgwa sajŏnch'ulp'ansa.

King, Ross. 1998. Nationalism and Language Reform in Korea: The Questione della Lingua in Precolonial Korea. In: Nationalism and the Construction of the Korean Identity. Eds. Hyung Il Pai and Timothy R. Tangherlini. 33-72. Berkeley, CA: Institute of East Asian Studies, University of California.

Knowles, Steve 2001. Postmodernism: Reasons to be Cheerful! In: Transforming Exclusion: Engaging Faith Perspectives. Eds. Hannah Bacon and Wayne Morris with Steve Knowles. 1-14. London and New York: T\&T Clark International.

Levenson, Joseph R. 1958, 1968. Confucian China and Its Modern Fate: A Trilogy. First 
Combined Edition. Berkeley, CA and Los Angeles: University of California Press.

Lew, Young Ick 1992. Kabogyŏngjang'yŏn'gu [Studies on the Kabo reforms]. Vol. 1. Seoul: Hallimdaehak'yo asiamunhwayŏn'guso.

Lew, Young Ick 2001. The Tonghak Uprising and the Kabo Reforms. Lectures presented at Yonsei University, Graduate School of International Studies (GSIS), in Seoul, October 2001.

Lyotard, Jean-François 1979, 1984. The Postmodern Condition: A Report on Knowledge. Trans. Geoff Bennington and Brian Massumi. Theory and History of Literature, Vol. 10. Minneapolis, MN: University of Minnesota Press.

Lyotard, Jean-François 1988. L’inhumain: Causeries sur le temps [The inhuman: Reflections on time]. Paris: Galilee.

Malpas, Simon 2005. The Postmodern. London and New York: Routledge.

Miriam-Webster Dictionary 2017. https://www.merriam-webster.com/(accessed 9 February 2017).

Rivlina, Alexandra 2015. Global English-related Digraphia and Roman-Cyrillic Biscriptal Practices. Procedia - Social and Behavioral Sciences, Vol. 236, December 2016, 207-212. Kongmunsik (Edict on Public Writing) 1894. In: Kab'ogyŏngjang (Kabo reforms).

Pak Chong-guk 2012. Uri kuk'ŏhaksa [The history of the studies of our national language]. Seoul: Sejonghakwŏn'guwŏn. G. Pak 2012:

Pieper, Daniel O. 2011. Han'gul for the Nation, the Nation for Han'gul: The Korean Language Movement, 1894-1945. Master's thesis. Washington University, St. Louis, MO.

Polletta, Francisca 1998. "It Was like a Fever ...” Narrative and Identity in Social Protest. Social Problems, Vol. 45, No. 2, May 1998), 137-159.

Ri, Chong-hyŏn 1991. Chosŏnburŭjoaminjokundongsa [History of Korea's bourgeois movement]. P’yŏngyang: Kwahakbaekgwasajŏnjonghapch'ulp'ansa.

Ricoeur, Paul 1980. Narrative Time. Critical Inquiry, Vol. 7, No. 1, On Narrative, Autumn 1980, 169-190.

Robinson, Michael E. 1986. Nationalism and the Korean Tradition, 1896-1920: Iconoclasm, Reform, and National Identity. Korean Studies, Vol. 10, 35-53.

Robinson, Michael E. 1988. Cultural Nationalism in Colonial Korea, 1920-1925. Seattle: University of Washington Press.

Shin, Gi-Wook 2006. Ethnic Nationalism in Korea: Genealogy, Politics and Legacy. Stanford, CA: Stanford University Press.

Song, Jae Jung 1994. Language Policies in North and South Korea: Divergence and Convergence. Language Quarterly, Vol. 32, No. 1, Summer/Fall, 205-212.J. J. Song, 1994: 206). 
Schmid, Andre 2002. Korea Between Empires, 1895-1919. New York: Columbia University Press.

Schultz, William 1998. The Ambivalence of Out Postmodern Condition: Lyotard's Diagnosis and Prognosis. (Originally published in Greek in the journal Diavazo, September 1998, 66-80. http://www.costis.org/x/lyotard/schultz.htm (accessed on 14 April 2018).

Siekmeier, James F. 2017. Latin American Nationalism: Identity in a Globalizing World. London and New York: Bloomsbury Academic.

Shim, Jae Kee 1998. Kukhanja hon'yong-ŭi t’adangsŏng-e kwanhan yŏn'gu [A study on the validity of mixed-script]. Kwan'ak'ŏyŏn'gu [Kwan'ak language research]. Vol. 23, 5-39. Seoul: Seouldaehakyo kuk’ŏkungmunhakgwa.

Shim, Jae Kee 2004. Kunhanhonyongnon-ŭi yŏksa, munhwajŏk paegyŏng [A historical and cultural background to the han'gŭl-hanja mixed script]. In: Hanjagyoyuk-gwa hanjajŏngch'aek-e taehan kukjehaksulhoeŭi [International conference on the education and policy of Chinese characters]. 71-103. Seoul: Han'guk'ŏ'mun'gyoyuk' yŏn' guhoe.

Shin, Yong-ha 1976. Tongniphyŏphoe-wa kaehwaundong [The independence club and enlightenment movement]. Seoul: Sejongdaewang'kinyŏmsaŏphoe.

Shin, Yong-ha 1984. Minjok hyŏngsŏng-ŭi iron [Theory of the formation of the nation]. Han'guk sanhoe yŏn'gu [Society of sociological research] No. 7. Seoul: Seoul National University.

Shin, Yong-ha 1986. 1894nyŏn-ŭi sahoesinbunje-ŭi p'yeji [The 1894 termination of the social status system]. Kyujanggak, Vol. 9, 49-84. Seoul:

Shin, Yong-ha 2000. Modern Korean History and Nationalism. Trans. N. M. (Mohan) Pankaj. Seoul: Jimoondang Publishing Company.

Smith, Anthony D. 2009. Ethno-symbolism and Nationalism: A Cultural Approach. London and New York: Routledge.

Somers, Margaret R. 1992. Narrativity, Narrative Identity, and Social Action: Rethinking English Working-Class Formation. Social Science History, Vol. 16, No. 4, Winter 1992, 591-630.

Somers, Margaret R. 1994. The Narrative Constitution of Identity: A Relational and Network Approach. Theory and Society, Vol. 23, No. 5, October 1994, 605-649.

Stephens, John; Robyn McCallum 1998. Retelling Stories, Framing Culture: Traditional Story and Metanarratives in Children's Literature. New York and London: Garland Publishing, Inc.

Strnad, William 2016. On Shadow and Form: Korean Nationalism's Digraphic Conflict. International Journal of Korean Humanities and Social Sciences, Vo. 2, 87-121.

Thompson, Paul 2012. Both Dialogic and Dialectic: "Translation at the Crossroads". Learning, Culture and Social Interaction, Vol. 1, Issue 2, June 2012, 90-101. 
Unger, J. Marshall 2001. Functional Digraphia in Japan as Revealed in Consumer Product Preferences. International Journal of the Sociology of Language, Vol. 150, 141-152. Unger, 2001

Unseth, Peter 2005. Sociolinguistic Parallels between Choosing Scripts and Languages. Written Language and Literacy, Vol. 8, No. 1, 19-42.

Vološinov, Valentin N. 1929, 1973. Marxism and the Philosophy of Language. Tr. Ladislav Matejka and I. R. Titunik. Cambridge, MA and London: Harvard University Press.

Vygotsky, Lev S. 1934, 1986. Thought and Language. Revised Edition. Tr. Eugenia Hanfmann and Gertrude Vakar. Ed. Alex Kozulin. Cambridge, MA and London: The MIT Press.

Wallerstein, Immanuel 1990. Culture as the Ideological Battleground of the Modern World. In: Global Culture. Ed. Mike Featherstone. 31-56. New York: Sage Publications.

Wang, Sixiang 2014. The Sounds of Our Country: Interpreters, Linguistic Knowledge, and the Politics of Language in Early Chosŏn. In: Rethinking East Asian Languages, Vernaculars, and Literacies. 58-95. Ed. Benjamin A. Elman. Leiden and Boston, MA: Brill.

White, Hayden 1973, 2014. Meta-History: The Historical Imagination in Nineteenth Century Europe. Fortieth Anniversary Edition. Baltimore, MD: Johns Hopkins University Press.

White, Hayden 1980. The Value of Narrativity in the Representation of Reality. Critical Inquiry, Vol. 7, No. 1, On Narrative, Autumn 1980, 5-27.

White, Hayden 1984. The Question of Narrative in Contemporary Historical Theory. History and Theory, Vol. 23, No.1, February 1984, 1-33.

Wodak, Ruth 2007. "Pragmatics and Critical Discourse Analysis: A Cross-Disciplinary Inquiry”. Pragmatics \& Cognition, Vol. 15, No. 1, 203-225.Wodak, 2007

Yi, Eung-ho 1974. Mi kunjŏnggi-ŭi hang'ŭl undongsa [History of the Han'gŭl movement during the period of the United States interim military government]. Seoul: Sŏngch’ŏngsa.

Yi, Hye-ryŏng 2005. Hanjainsik-gwa kŭndae-ŭi naesŏnŏllit’i [Knowledge of hanja and nationality of modern language]. In: Minjokmunhaksayŏn'gu [Research on the history of national culture]. Vol. 29, 210-241. Seoul: Minjok munhak sahakhoe.

Yi, Ki-mun 1987. Han'gŭl-ŭi yŏn'gu-wa pogŭp [Research on and dissemination of han'gŭl]. In: Han minjok tongnip undongsa [A history of the independence movement of the Korean nation], Vol. 2. Ed. Kuksa p'yŏnch'an wiwŏnhoe. 102-127. Seoul: Kuksa p'yŏnch'an wiwŏnhoe.

Yŏnseidae on’ŏjŏngboyŏn'guwŏn HKsaŏpdan 2012. Kŭndae kyemong kuk’ŏkungmun 
tamnon-ŭi hyŏndaejŏk haesŏk-ŭl wihayŏ [Unraveling Korean literature: For a contemporary interpretation of Korean language discourse during the modern enlightenment period]. Seoul: Pakijongch'ulp'ansa.

Zíma, Petr 1974. Digraphia: The Case of Hausa. Linguistics, Vol. 124, 57-69. 